\title{
The International Criminal Court: An Historic Step to Combat Impunity
}

\author{
William A. Schabas
}

\begin{abstract}
Fifty years after it was originally promised in article VI of the Genocide Convention, the International Criminal Court (ICC) has finally seen the light of day. It was created by the Rome Conference, which met from June 15 to July 17,1998, following four years of intense negotiations. This article provides an overview of the Rome Statute for an International Criminal Court along with a discussion of entry into force of the treaty.
\end{abstract}

\section{Précis}

Cinquante ans après que sa création ait été promise à l'article VI de la Convention contre le génocide, la Cour pénale internationale (CPI) a finalement vu le jour. Elle fut crééeà l'occasion de la Conférence de Rome, tenue du 15 juin au 17 juillet 1998, après quatreans d'intenses négociations. Cet article donne une vue d'ensemble du Statut de Rome pour une Cour criminelle pénale, accompagnée d'une discussion de l'entrée en vigueur du traité.

What will be known as the Rome Statute of the International Criminal Court was adopted on July 17, 1998, at the conclusion of the United Nations Diplomatic Conference of Plenipotentiaries on the Establishment of an International Criminal Court. The Statute, which is an international treaty, provides for the establishment of an international criminal court upon its ratification or accession by sixty States, a process that may take several years. Once the treaty comes into force, the Court will be in a position to try individuals for four categories of international crimes: genocide, crimes against humanity, war crimes and aggression. There are important pre-con-

William A. Schabas, M.A., LL.D., is Professor, Département des sciences juridiques, Université du Québec à Montréal. ditions to the exercise of jurisdiction by the Court. First, national justice systems must have been deficient; in effect, the Court is only "complementary" to existing domestic judicial mechanisms and may operate only when they have failed, for a variety of reasons specified in the Statute, to act. Second, the Court may only try individuals who are nationals of States parties to the treaty, or individuals who are accused of committing crimes on the territories of States parties. If found guilty, offenders may be sentenced to terms of life imprisonment.

Theadoption of the Rome Statute is the conclusion of efforts at the establishment of international justice which can be traced to the end of the First World War. But the limited examples of international criminal justice for such serious crimes have been confined to ad hoc institutions, created so as to deal, retroactively, with particular situationsNazi Germany, Japan, the former Yugoslavia and Rwanda. The new Court will operate only prospectively, trying crimes that occur after its creation. As a permanent international institution, it will work in close association with the United Nations although it is formally independent.

This paper presents a brief overview of the Rome Statute and the features of the new International Criminal Court.

\section{Historical Background}

Historians of international criminal law often begin with the medieval trial of SirPeter of Hagenbach, who was tried and executed because of his reign of terror in the fortified town of Breisach. ${ }^{1}$ But the Treaty of Versailles provides the first contemporary experiment in international justice. Article 227 contemplated the trial of the Kaiserby an international tribunal, although this never took place because of the Netherlands' refusal to extradite. ${ }^{2}$ The Treaty of Versailles also envisaged the trial before Allied mili- tary tribunals of persons accused of violating the laws and customs of war. ${ }^{3}$ Germany subsequently opposed the surrender of those chosen for trial by the Allies, arguing that the trial of many of its principal military and naval leaders would imperil its Government's existence. A compromise was effected, deemed to be compatible with article 228 of the Versailles Treaty, whereby the Supreme Court of the Empire in Leipzig would judge those charged by the Allies. Lists were prepared naming 896 Germans, but only a handful were ever actually brought to trial under charges laid according to Germany's Military Penal Code and its Imperial Penal Code. ${ }^{4}$

During the interior period, there were attempts to create a permanent international criminal court, and in 1937 a treaty to this effect was signed by thirteen states, but it never came in to force. ${ }^{5}$ As the Second World War drew to a close, the United Nations War Crimes Commission also prepared a draft statute for an international criminal court. ${ }^{6}$

The great breakthrough was the adoption on August 8, 1945, in London, of the Charter of the International Military Tribunal..$^{7}$ The Charter was actually used for only one trial, that of twenty-three "major war criminals" of the Nazi regime which began in November 1945 and finished on October 1, 1946. The Tribunal was empowered to convict for war crimes, a concept already well-established in international law, but also for crimes against peace and crimes against humanity, whose recognition was more controversial. The International Military Tribunal's judgment is a seminal historical document on the atrocities of the Nazi system. ${ }^{8}$ Companion proceedings were undertaken against Japanese war criminals before the Tokyo Tribunal under a statute that was modelled on the Nuremberg Charter. ${ }^{9}$ Most Naziand Japanese war crimi- 
nals, as well as their collaborators, were tried before national courts of the States where the crimes took place or by military tribunals set up by the Allied victors. In Germany, the most important of these were held at Nuremberg from 1946 to 1948 by American military courts, pursuant to Control Council Law No. $10 .{ }^{10}$

The Convention for the Prevention and Punishment of the Crime of Genocide, adopted December $9,1948,{ }^{11}$ envisions the eventual establishment of an international criminal court. ${ }^{12}$ In 1950 , following work in International Law Commission on the establishment of an international criminal jurisdiction, the General Assembly of the United Nations agreed to set up a committee charged with preparing a draft treaty. ${ }^{13}$ But after two postponements in the General Assembly, ${ }^{14}$ the international criminal court project was shelved for more than thirty years. At the request of the Assembly, the International Law Commission eventually returned to the issue. ${ }^{15}$ The Commission presented its final report to the General Assembly in 1994. ${ }^{16}$ But in the meantime, events had overtaken the Assembly. In May, 1993, the Security Council, in an innovative move that relied on Chapter VII of the Charter of the United Nations, created an ad hoc international tribunal for crimes committed in the former Yugoslavia since 1991. ${ }^{17}$ In November, 1994, it took a similar step for Rwanda. ${ }^{18}$

The General Assembly decided to proceed with the project, and struck an ad hoc Committee to examine the draft prepared by the International Law Commission. ${ }^{19}$ The Committee met during 1995 and reported back to the Assembly. ${ }^{20}$ Clearly, much more workneeded to bedone, and the Assembly convened a Preparatory Committee intended to prepare the ground for a diplomatic conference. ${ }^{21}$ The Preparatory Committee met for sessions of several weeks in 1996,1997 and 1998. Its final report was submitted to the Diplomatic Conference held in Rome at the head quarters of the Food and Agriculture Organization, over five weeks beginning June 15 , 1998. ${ }^{22}$ The Conference, in keeping with contemporary practice, eschewed vot- ing on various proposals and attempted to resolve contentious matters by consensus, a process which results in provisions with which nobody is entirely happy but with which everybody can live. By July 16, most of the issues in the Statute, including an immense number of technical details relating to comparative criminal law, had been resolved, although a few major and politicallycharged questions remained to bedetermined. Early in the morning of July 17 , which was the final day of the Rome meeting, the Bureau of the Conference, chaired by Canadian diplomat Philippe Kirsch, presented the assembled delegates with a compromise "package" drawing on the consensus texts worked out over the previous five weeks and recommending solutions for the most difficult issues. The proposal met with general agreement, although a few voices were raised in opposition, notably those of India and the United States. In the final plenary, the United States insisted that the Statute be put to a vote, despite the fact that its near unanimous support was already evident. The delegates voted in favour of the Statute, by 120 to 7 , with 21 abstentions. ${ }^{23}$

\section{Complementarity}

The fundamental premise of the Court's existence is the principle of "complementarity." The Statute gives national legal systems the first chance to try offenders. Only when domestic justice refuses to act may the International Criminal Court exercise jurisdiction. The principle is in some ways analogous to the approach taken by international human rights treaties, which allow the international adjudicative organs to be petitioned by individuals only when domestic remedies havebeen exhausted. ${ }^{24}$ In many situations, domestic courts will be unwilling to proceed against their own nationals, who may be in positions of political authority, for such crimes. The Court will then be empowered to act. There may also be cases where the national legal system has broken down and is simply unable to function. Situations of complementary are also expect to arise when national legal proceedings have amounted to sham trials, held for the purpose of shielding the person concerned from criminal responsibility for crimes within the jurisdiction of the Court. In addition, the Courtmay exercise jurisdiction when national trials are not conducted independently or impartially in accordance with the norms of due process recognized by international law, or are conducted in a manner which, in the circumstances, is inconsistent with an intent to bring the person concerned to justice. ${ }^{25}$

Complementary shifts the onus back to States to ensure that they have effective mechanisms for the trial of international criminals. States are, in effect, entitled under international law to try not only their own war criminals, something they are often loathe to do, butalso those who have no connection with the State itself but, for various reasons, find themselves on its territory. The concept is known as "universal jurisdiction" and an increasing number of States have amended their criminal legislation in order to allow national Courts to undertake such trials. ${ }^{26}$ If the principle of complementarity is effective, then the International Criminal Court will have a small caseload. The problem of impunity will have been solved by in effect sending the ball back to those who have primary responsibility for prosecution, the national Courts.

The regime of complementarity stands in contrast to that of "primacy," which is what is provided for the ad hoc tribunals. ${ }^{27}$ If the prosecutor of the $\mathrm{Yu}$ goslav or Rwanda tribunals wishes to take a case before the ad hoc tribunals, there is no question of whetherdomestic efforts at justice have been inadequate. In the Tadic case, the Yugoslav tribunal sought jurisdiction over an offender whose proceedings had already begun in Germany. ${ }^{28}$ There was no suggestion that justice would not be done by the German courts. But the Rwanda tribunal, in a case where it initially sought to exercise jurisdiction over an individual who had been charged by the national courts of Rwanda, decided to withdraw its request and to allow the Rwandan courts to exercise justice. ${ }^{29}$ 


\section{Subject Matter Jurisdiction}

The International Criminal Court has jurisdiction over four categories of crime: genocide, crimes againsthumanity, war crimes and aggression. ${ }^{30}$ These offences are generally recognized as being at the core of international criminal law. They have formed the basis of previous international prosecutions by tribunals at Nuremberg, Tokyo, The Hague and Arusha, and are considered to have a customary legal basis, even in the absence of a precise text. The essence of these four crimes is that they essentially correspond to serious violations of human rights, although somedispute whether the Court and its Statute fall within the scope of human rights law. During the drafting of the Rome Statute, there were efforts to include what are known as "treaty crimes," violations of specific conventions dealing with such matters as hijacking, terrorism, drug trafficking and torture. But the delegates to the Diplomatic Conference were unable to reach consensus on mechanisms to include these somewhat secondary matters within the jurisdiction of the Court, and they were eventually excluded.

Genocide is the first crime to be enumerated in the Statute of the Court. ${ }^{31}$ It was first defined in a General Assembly Resolution in 1946, and subsequently in the 1948 Convention on the Prevention and Punishment of the Crime of Genocide. ${ }^{32}$ According to the Convention, genocide consists of killing or other acts with an intent to destroy, in whole or in part, a racial, ethnic, national or religious group. The definition in the 1948 Convention has often been criticized for its omission of political, social, economic and other groups, ${ }^{33}$ but the delegates to the Diplomatic Conference wisely chose not to tamper with a widely accepted text. In any case, any lacunae in the Convention definition fall under the heading of crimes against humanity, and there is consequently no danger of impunity.

Crimes against humanity represents an important evolution in the law, because any requirement that such crimes be committed within the context of an armed conflict is eliminated. This had been the case at Nuremberg, ${ }^{34}$ and the Security Council had perpetuated the suggestion by imposing a similar requirement in the case of the former Yugoslavia. ${ }^{35}$ Nevertheless, the International Criminal Tribunal for the former Yugoslavia has stated that customary law requires no such nexus with armed conflict and crimes against humanity, ${ }^{36}$ and the Rome Statute establishes this principle beyond any doubt. Crimes againsthumanity are defined as being acts committed as part of "a widespread or systematic attack directed against any civilian population, with knowledge of the attack." 37 The acts themselves are enumerated in the text, and include murder, extermination, enslavement, deportation or forcible transfer of population, imprisonmentor other severe deprivation of physical liberty in violation of fundamental rules of international law, torture, enforced disappearance, apartheid, persecution and other inhumane acts. Particularly important is the attention given to gender-related crimes, which are defined as "[r]ape, sexual slavery, enforced prostitution, forced pregnancy, enforced sterilization, or any other form of sexual violence of comparable gravity." The reference to "forced pregnancy" was extremely controversial as some States saw this as an implicit recognition of the right to abortion. Use of the term "gender" in the provision dealing with persecution was also a source of considerable debate, and led, as a compromise, to the addition of a definition: "the term 'gender' refers to the two sexes, male and female, within the context of society." 38

On the scale of seriousness, war crimes generally fall somewhat below the thresholds for genocide and crimes against humanity, if only because they are punishable as individual acts and donot require any special intentelement or evidence that they are widespread or systematic. However, the Rome Statute sends a signal to the prosecuted in the chapeau of the war crimes provision: "The Court shall have jurisdiction in respect of war crimes in particular when committed as a part of a plan or policy or as part of a large-scale commission of such crimes." 39 The war crimes provisions are extremely detailed, and represent an obsession with codification that may ultimately result in excessively narrow interpretations by the Court. War crimes are divided into four categories, the first two concerned with international armed conflict, the second two with internal armed conflict. They correspond to those offences known as "gravebreaches" of the Geneva Conventions of August 12, $1949^{40}$ and of Protocol Additional $I, 41$ to serious violations of the laws and customs of war and in particular of the Hague Regulations, to violations of common article 3 of the Geneva Conventions, and to certain breaches of Protocol Additional II. ${ }^{42}$ Despite the fact that the detailed provisions largely reflect customary norms, there are some innovations, for example in the prohibition of recruitment of child soldiers. ${ }^{43}$ Another new offence, " $t \mathrm{t}]$ he transfer, directly or indirectly, by the Occupying Power of parts of its own civilian population into the territory it occupies, or the deportation or transfer of all or parts of the population of the occupied territory within or outside this territory,"44 was decried by Israel as a cynical political gambit by its adversaries and led Israel to vote against the Statute. One of the great inadequacies of the list is its failure to adopt a general prohibition of weapons that cause unnecessary suffering. The Statute prohibits use of poisonous gas, ${ }^{45}$ and of dumdum bullets, ${ }^{46}$ butnotchemical, biological and nuclear weapons! ${ }^{47}$

Aggression was the most difficult of the crimes to define, although a General Assembly Resolution provides all of the elements necessary for a satisfactory text. ${ }^{48}$ The heart of the problems was clarifying the role of the Security Council which, under the Charter of the United Nations, has the mandate to determine when aggression occurs. ${ }^{49}$ Despite the efforts of the Non-Aligned Movement, no consensus could be reached. Thus, aggression is part of the subject matter jurisdiction of the Court, but subject to the subsequent adoption of a provision by the Assembly of States Parties defining the crime and setting out the condi- 
tions under which the Court shall exercise jurisdiction with respect to this crime. ${ }^{50}$

The four crimes make up the "automatic jurisdiction" of the Court, in that any State, in ratifying the Statute, accepts jurisdiction over them. A last-minute compromise designed to lure France into the final consensus added the possibility of "opting out" on jurisdiction over war crimes. Under article 124, a State, on becoming a party to the Statute, may declare that, for a period of seven years after the entry into force of this Statute for the State concerned, it does not accept the jurisdiction of the Court with respect to war crimes. Such a "deal" was severely criticized at the close of the conference by some nongovernmental organizations. In practice, it represents a rather small concession. The history of international war crimes tribunals in Nuremberg, Tokyo, The Hague and Arusha shows that war crimes are rarely, if ever, prosecuted separately from crimes against humanity. In other words, once a war crime is of sufficient gravity to deserve the attention of an international prosecutor, it has attained a level of seriousness so as to meet the threshold for crimes against humanity. The possibility that individuals will escape international criminal responsibility because a few States decide to opt out pursuant to article 124 seems remote indeed, and can hardly be considered a major blemish on the Statute.

\section{Jurisdiction over the Offender}

The International Criminal Court may establish jurisdiction over individuals on two bases. They may be tried if they are nationals of a State party to the Stat$u t e$, and they may be tried if the crimehas been committed on the territory of a State party of the Statute. ${ }^{51}$ This result is a compromise between two extreme positions, vigorously defended at the Diplomatic Conference by Germany and the United States. Germany wished for the Court to exercise universal jurisdiction, given that the States parties would all be competent, as a question of international law, to exercise universal jurisdiction, and therefore in a position to transfer or delegate this to the international tribunal. The United States desired a far more limited scope for the Court, limiting its jurisdiction tonationals of a State party. In this way, as long as the United States remained outside the treaty regime, no American citizen could ever be tried by the International Court. The United States argued that the German proposal would eliminate any distinction between States that had ratified the Statute and those that had not. Germany answered that under the United States proposal, obvious candidates for the Court's jurisdiction would escape justice because of the unlikelihood that their own State would ever ratify the Statute.

Both proposals had their flaws. As the debate unfolded on the German proposal, it became clear that many States actually disagree with the proposition that universal jurisdiction exists for the core crimes as a question of customary law, even though this view has been widely defended by scholars. Thus, the Conference may well have set back the development of the law on this point by showing, academic commentators to the contrary, that the claims of universal jurisdiction to customary status may be exaggerated. By insisting upon an exaggeratedly optimistic conception of the law as it now stands, Germany may have achieved the opposite of what it intended. On this point, the United States noted its unsuccessful efforts to have Pol Pot prosecuted by such States as Canada, Spain and Israel under the universal jurisdiction provisions of their national legislations. Universal jurisdiction does not exist in reality, argued the United States. But in doing so, it seemed to defeat its own claim that the Court could not assume universal jurisdiction. If the United States was agreeable to prosecuting Pol Pot under universal jurisdiction, how could it oppose, as a question of principle, the International Court doing the same? The answer would appear to be that universal jurisdiction is acceptable for Cambodians butnot for Americans, acceptable for Pol Pot butnot for William Calley or RobertMcNamara.
The resulting provision means that during the foreseeable future, many international criminals will still escape the jurisdiction of the International Criminal Court. But this should surprise nobody, given the fact that the Court is created by treaty and is based on the consent of States. The argument that "rogueStates" will not ratify has its shortcomings, because the democracy of today may be therogueState of tomorrow, as the record in human rights treaties has shown. The two genocides in recent decades, those of Cambodia and Rwanda, were both committed on States parties to the Genocide Convention. ${ }^{52}$ In addition, many States may see the value in ratifying the Statute as a protection against foreign military intervention, even if aggression as such remains undefined. Had the Statute existed decades ago, Grenada, Panama, Cambodia and VietNam would all have been protected against war crimes committed by foreign soldiers on their own territory by virtue of their ratification. In conclusion, the jurisdiction over the person that is set out in the Rome Statute is incomplete yet sufficientenough to promise a Court that will make its mark against impunity.

\section{Relationship with the Security Council}

The two ad hoc tribunals were created by decisions of the Security Council of the United Nations, acting under Chapter VII of the Charter of the United Nations. Their potency and effectiveness derives from the binding force of Council decisions and the Council's ability to adopt further implementation measures. But any role for the Council carries with it the danger of political interference. The undemocratic composition of the Council, with its five permanent members all of whom have a veto power, representing an outdated conception of world power, makes any involvement for it even more unpalatable. In its $1994 \mathrm{draft}$ statute, the International Law Commission felt that political realities dictated a form of veto by the Security Councilon any prosecution by the Court. ${ }^{53}$ The proposed provision was widely inter- 
preted as meaning that a situation would escape the jurisdiction of the Court as long as it was on the agenda of the Council. A compromise proposal developed by Singapore at the August, 1997 meeting of the Preparatory Committee recognized a possible right for the Council to demand a stay of proceedings, but required the Council to act affirmatively by resolution, thus allowing one permanentmember or any seven of its members to block such a measure. The final version, article 16 of the Rome Statute, takes this a step further, requiring the Security Council to renew any such resolution every twelve months.

In exercising this extraordinary power, the Security Council is required to act pursuant to Chapter VII of the Charter, that is, in response to threats to the peace, breaches of the peace and acts of aggression. The Council has given this notion a large scope in recent years, reaching deep into the field of human rights in a manner that could hardly have been intended by the drafters of the Charter. In imposing a Chapter VII qualification as a criterion for Security Council intervention in the work of the Court, the Rome Statute would seem to give the Court the possibility of judicial review of Security Council decisions, a power that thus far has escaped organs created under the Charter itself.

It may well be argued that article 16 of the Rome Statute is completely unnecessary. If the Security Council is the supreme law-making body of the United Nations, pursuant to article 25 of the Charter of the United Nations, and if the obligations under the Charter prevail over any incompatibleobligation resulting from another treaty, then the Security Council could presumably order a stay of proceedings before the Court in any case, relying on Charter article 103. It is to be hoped that both bodies will respect the mission of the other, the Security Council exercising its power to intervene with prudence and circumspection and only in the rarest of cases, and the Court proceeding with great caution in matters pending before the Security Council that touch on sensitive issues of international peace and security.

\section{The "General Part" of the Rome Statute}

In contrast with the legal instruments upon which international prosecutions have been based in the past, the Rome Statute includes a bold new initiative in what is really comparative criminal law. The Statute contains what common-law criminal codes call a "general part" and what Romano-Germanic codes define as "general criminal law." These are basic rules governing the nonretroactivity of offences and punishments, participation in criminal offences by accomplices and conspirators, and the admissibility of defences such as duress, self-defence, mistake of fact or of law and obedience to superior orders. Much of this is highly technical and, in essence, a distillation of principles of law common to most if not all national systems.

One area in which international criminal law goes well beyond most domestic law is in its attitude to commanders or superiors. Under the command responsibility principle, developed at trials following the close of the Second World War, military commanders can be held liable for the acts of their subordinates even where there is noproof that an order was given or even that the commander knew of the acts committed by the subordinates. In its most extreme form, this amounts to a type of criminal liability for negligence. It was highly controversial when first bruited in 1945,54 but has since become more accepted, and the principle of command responsibility is recognized in Protocol Additional $\mathrm{I}^{55}$ as well as in the statutes of the ad hoc tribunals. ${ }^{56}$ The Rome Statute takes this one further step, providing for the command responsibility not only of those in a military hierarchy but also civilian superiors. Nevertheless, civilian superiors are held to a lower standard, and can only be prosecuted on this basis if they were wilfully blind as to the acts committed by those subject to their supervision. ${ }^{57}$

Codifying general principles may be aimed at fettering judicial discretion. This would seem to be the case with respect to the defence of duress or coer- cion. The International Criminal Tribunal for the former Yugoslavia, which has no detailed "general part" in its Statute, has had to make its own rulings on the admissibility of defences. In the case of duress, it has decided that such a defence may neverbeentertained in the case of crimes against humanity. ${ }^{58}$ But the Rome Statute overrules the Tribunal, allowing for the defence of duress to any charge before the Court. ${ }^{59}$ The Rome Stat$u$ te also departs from existing international criminal law in the case of the defence of superior orders. A text in the Nuremberg Charter formally outlawed resort to such a defence, saying theargument could only be invoked in mitigation of sentence but not to challenge guilt. ${ }^{60}$ Similar provisions appear in the Statutes of the two ad hoc tribunals. But the Rome Statute allows the defence on the condition that the order not be "manifestly unlawful." 61 While it does not completely exclude the defence in cases of genocide and crimes against humanity, it does state that orders to commit such crimes are, by definition, manifestly unlawful. Although it codifies the rules governing some defences, the Statute does not prevent the Court from admitting other defences, ${ }^{62}$ and under this provision it may eventually allow defences such as military necessity and reprisal.

\section{Procedure}

Cases before the Courtmay be initiated by any of the States parties, by the Security Council acting pursuant to Chapter VII of the Charter of the United Nations, and by the Prosecutor, acting proprio motu. ${ }^{63}$ In the latter case, the Prosecutor cannot proceed until authorization has been obtained from the Pre-Trial Chamber of the judges. In cases where the States parties or the Security Council initiate the prosecution, the Prosecutor may in the exercise of his or her discretion decide to drop the case, but in such circumstances must justify its decision before the Pre-Trial Chamber. ${ }^{64}$

The Office of the Prosecutor is a separate and independent organ of the Court. It is headed by the Prosecutor, who is assisted by one or more Deputy Prosecutors. ${ }^{65}$ The Prosecutor and the 
Deputy Prosecutors areelected by secret ballot by an absolute majority of the members of the Assembly of States Parties. The Deputy Prosecutors shall be elected in the same way from a list of candidates provided by the Prosecutor. The independence of the Prosecutor was a major issue in the preparatory work of the Statute, someStates invoking the improbable scenario of the out-ofcontrol "Dr. Strangelove prosecutor." Judicial review of the Prosecutor by the Pre-Trial Chamberwas the compromise formula enabling an enlargement of the Prosecutor's autonomous powers.

There are to be eighteen judges, elected on secret ballot by a two-thirds majority of the Assembly of States Parties. The judges are to be nominated by the States parties and are drawn from two groups, specialists in criminal law and in international law, and are expected to be representative of the major legal systems. The Statute specifically provides for "[a] fair representation of female and male judges," ${ }^{166}$ a standard that falls somewhat short of calls for full gender balance but that will certainly prevent the Court from emulating the International Court of Justice, which had its first woman member in history only in 1996. Once elected, the judges elect three of their number, the President, and the two Vice-Presidents, who together make up the Presidency. The Presidency is responsible for the administration of the Court and other functions established by the Statute. ${ }^{67}$ Members of the Presidency sit full-time at the Court's seat in The Hague, the remaining fifteen judges being on call to sit as cases arise. The President sits on the Appeals Division together with four other judges. The Court also has a Trial Division and a Pre-Trial Division, each made up of no less than six judges. The Statute suggests that the international law specialists will tend to sit in the Appeals division, whilst the criminal law experts, particularly those with significant trial experience, will be directed towards the Trial and Pre-Trial Divisions. Trials are heard by benches of three judges who decide by majority vote. The Pre-Trial Chambers are com- posed of either three judges or by a single judge, depending on the matter before the Court.

The Registry, headed by the Registrar, is "responsible for the non-judicial aspects of the administration and servicing of the Court." ${ }^{\prime \prime 8}$ The Registrar is elected by an absolute majority of the judges, but taking into account any recommendation by the Assembly of States Parties.

Both investigation and trial are governed by procedural rules that draw on both inquisitorial and accusatorial legal approaches, that is, the commonlaw and Romano-Germanic systems. For example, the operation of the Pre-Trial Chamber is in many ways analogous to that of the chambre d'accusation in the French system. ${ }^{69}$ Like the instructing magistrate of the inquisitorial system, the Prosecutor is required to "investigate incriminating and exonerating circumstances equally." ${ }^{\prime 70}$ The provisions governing trial leavemany of the details to the Rules, yet to be adopted, and do not indicate any clearbias favourable to either inquisitorial or accusatorial systems. Practice before the ad hoc tribunals has shown that procedures vary considerably depending on the predisposition of the presiding magistrate, and that within general provisions of the sort found in the Statute there is a considerable degree of flexibility with respect to the orientation of the procedural regime. In any case, by the time a matter gets to trial, even theinquisitorial system becomes more and more accusatorial. One aspect of the inquisitorial system is essentially ruled out, however, the trial in absentia. While the guilty plea procedure familiar to common law systems is allowed for, a detailed provision carefully regulates its operation. ${ }^{71}$

Detailed provisions outline the rights of suspects or accused at both the investigation and trial phase of the proceedings. These are drawn from international human rights instruments, principally article 14 of the International Covenant on Civil and Political Rights, ${ }^{72}$ but in some cases go beyond the existing texts. For example, both the suspect at the investigation phase and the accused at the trial phase have the right to remain silent without their silence being used by the Prosecution in any way to suggest culpability. ${ }^{73}$ While this right is recognized in some legal systems, others do not respect it, and there is no authority on an international level to support it being considered a fundamental right. The accused is entitled "[t]o be informed promptly and in detail of the nature, cause and content of the charge, in a language which the accused fully understands and speaks."74 This is somewhat broader than the International Covenant, which states that the accused is entitled "[t]obeinformed promptly and in detail in a language which he understands of the nature and cause of the charge against him." ${ }^{15}$ Other "new" rights are also granted to the accused: to make an unsworn oral or written statement in his or her defence; ${ }^{76}$ and not to have imposed on him or her any reversal of the burden of proof or any onus of rebuttal. ${ }^{77}$ There are no "reverse onus" references in the definitions of crimes so the import of the latter right is unclear. But judges might give it a broad interpretation and rule that a variety of evidentiary presumptions, which are really no more than common-sense deductions from the proof, run afoul of the provision. It also remains to be seen whether human rights tribunals, internationally or domestically, will be inspired by the innovations of the Statute and use its terms in a dynamicinterpretation of the somewhat aging provisions under which they are governed.

Upon conviction, the Courtmay sentence an offender to life imprisonment, or to a fixed term with a maximum of thirty years. ${ }^{78}$ The Court may only impose life imprisonment "whenjustified by the extreme gravity of the crime and the individual circumstances of the convicted person." Sentences are to be served in prisons of States parties to the Statute, in accordance with agreements negotiated with the Court. ${ }^{79}$ In all cases, the sentence is reviewed after twothirds of it has been served, or in the case of a sentence of life imprisonment, after 
twenty-five years. ${ }^{80}$ The sentencingprovisions represented an extremely delicate compromise. Several States in Latin America, have constitutional provisions prohibiting life imprisonment. Others, in Europe, have recognized the same principle through the caselaw of their constitutional courts. But there were extreme views on the other end, particularly from many Arab and Islamic States, and Commonwealth Caribbean States, desiring that the Statute recognize the death penalty. Capital punishment was out of the question, and even the United States, which employs the death penalty enthusiastically within many of its internal jurisdictions, spoke againstits use as an international sanction. Were the death penalty to be allowed under the Rome Statute,many Statesmight have refused to cooperate with the Courtinmatters of extradition or surrender. By excluding the death penalty and allowing life imprisonment only in extremely serious cases, and always subject to mandatory review, the Statute sends a progressive message of clemency that, it is to be hoped, will support the efforts of penal law reformers within domestic systems. $^{81}$

A growing concern within international human rights law for the situation of the victims of human rights abuses is reflected in several provisions of the Statute. ${ }^{82}$ The most important is article 75, which allows the Court to provide for reparations to victims of the crimes that it adjudicates. The Court is to "establish principles" with respect to reparations, including restitution, compensation and rehabilitation. Upon request and even, in exceptional circumstances, on its own initiative, the Court may "determine the scope and extent of any damage, loss and injury to, or in respect of, victims." The Court is empowered to order a convicted person to make reparation. A Trust Fund is established under the Statute into which monetary reparations are to be paid and from which they are to be distributed. ${ }^{83}$ Execution of these orders will depend largely upon co-operation by States parties, and may require them to make amendments to their own civil legislation.

At the heart of the obligations assumed by States parties is the duty to cooperate with the Court at various phases of investigation and trial. ${ }^{84}$ Upon receipt of an arrest warrant from the Prosecutor, States parties are required to giveeffect to the warrant. ${ }^{85}$ The Statute refers to "surrender" rather than "extradition" out of concern that States may invoke domestic legal provisions that prohibit "extradition" of their own nationals. ${ }^{86}$ Any interpretation of the Statute allowingStates to refuse to extradite their own nationals would have devastating consequences for the effectiveness of the Court.

\section{Conclusion}

The Statute will come into force upon its ratification by sixty States. Estimates vary considerably about how long this may take, from a few years to as long as a decade or more. Some argue, as well, that as long as big States such as India, China and the United States of America stay outside the system, the Court can never be really effective. But there are good reasons to remain optimistic about an early entry into force of the Statute and a dynamic and vigorous role for the Court, even if important countries and even continents remain somewhat aloof.

In the final vote on the Statute, 120 of the delegations voted in its favour. This is an impressive critical mass of States, many of them quite small and quite underdeveloped, for whom the creation of the Court is an important development. For example, with a few exceptions, sub-Saharan Africa voted strongly for the Court and supported the work of the Diplomatic Conference. This is an area plagued by armed conflict where many States are desperately searching for mechanisms to reduce and to prevent further disorder. The International Criminal Court offers them one element towards some solutions. States thathave experienced armed conflict involving foreign military forces should also have no difficulty appreciating the interest of the Court. Ratifica- tion of the Statute will bring the international institution to bear on all atrocities committed within their own borders, even by foreign soldiers.

In the end, most States will ratify the Statute for the same reasons that they have ratified international human rights instruments. All of the major human rights treaties have ratification rates that now go well beyond 100 . The Geneva Conventions have been ratified by virtually every State in the world. Why should there be any less enthusiasm to ratify the Statute? The history of human rights and humanitarian instruments demonstrates that narrow self-interest has little to do with why States decide to participate in such regimes rather than stay aloof. From this perspective, sixty ratifications should be attainable and in a relatively short time.

The promise of the Court is that it will help to reduce human rights violations. This is often presented as a question of general deterrence. The end of impunity and the threat of punishment, it is said, will discourage others from committing similar offences. The premise is difficult toprove or to disprove, but it is certainly questionable. Is it realistic to conclude that Hitler, Goering, Eichmann, Pol Pot, Karadzic and Bagosora would have been deterred by the threat of punishment? Although deterrence is certainly somewhere on the periphery of international justice, the core of the International Criminal Court may well have more to do with theestablishment of the truth of major atrocities in circumstances where domestic courts are unable or unwilling to act. For example, the principal contribution of the Nuremberg judgment may well be its clarification of the facts of the Nazi atrocities. Nuremberg puts the truth of the Holocaustbeyond question, something that continues to elude "historians." The Hague is doing the same for Bosnia, and Arusha for Rwanda. The Rome Statute confirms the valuable accomplishments of the tribunals at Nuremberg, Tokyo, The Hague and Arusha, and ensures that their legacies will continue. It is an historic step in the international protection of human rights. 


\section{Notes}

1. RobertK. Woetzel, The Nuremberg Trials in International Law, London: Stevens \& Sons, 1962, at pp. 19-20.

2. Treaty of Peace between the Allied and Associated Powers and Germany ("Treaty of Versailles"), 1919 T.S. 4.

3. Ibid., art. 228.

4. Although most of the trials were rather perfunctory, two important precedents that continue to be cited to this day addressed the question of the defence of superior orders: Empire v. Dithmar and Boldt (Hospital Ship "Llandovery Castle"), (1921) 21 I.L.R. 437, 16 A.J.I.L. 708, German War Trials, Report of Proceedings before the Supreme Court in Leipzig, Cmd. 1450, London: H.M.S.O., 1921, pp. 56-57; Empire v. Neumann (Hospital Ship "Dover Castle"), (1921) 21 I.L.R. 430, 16 A.J.I.L. 704, German War Trials, Report of Proceedings before the Supreme Court in Leipzig, Cmd. 1450, London: H.M.S.O., 1921, pp. 12-13. The two decisions are considered by the Supreme Court of Canadain R.v.Finta, [1994] 1 S.C.R. 701, 88 C.C.C. (3d) 417, 112 D.L.R. (4th) 513, 150 N.R. 370.

5. Convention for the Creation of an International Penal Court, Geneva, November 16, 1937, in Benjamin Ferencz, An International Criminal Court: A Step Towards World Peace-A Documentary History and Analysis, Dobbs Ferry, N.Y.: Oceana, 1980.

6. "Draft Convention for the Establishment of a United Nations War Crimes Court," United Nations War Crimes Commission, Doc. C.50(1), September 30, 1944, in Benjamin Ferencz, An International Criminal Court: $A$ Step Towards World Peace-A Documentary History and Analysis, Dobbs Ferry, N.Y.: Oceana, 1980.

7. Agreement for the Prosecution and Punishment of Major War Criminals of the European Axis, and Establishing the Charter of the International Military Tribunal (I.M.T.), (1951) 82 U.N.T.S. 279.

8. France et al. v. Goering et al., (1946) 23 Trial of the Major War Criminals before the International Military Tribunal, 13 I.L.R. 203, 41 A.J.I.L. 172.

9. Special Proclamation by the Supreme Commander for the Allied Powers at Tokyo, 4 Bevans 20, as amended, 4 Bevans 27 ("Charter of the Tokyo Tribunal").

10. Control Council Law No. 10, Punishment of Persons Guilty of War Crimes, Crimes Against Peace and Against Humanity, December 20, 1945, Official Gazette Control Council for Germany. Canada only held a handful of such trials, showing a distaste for war crimes prosecutions that has continued to this day: Patrick Brode, Casual Slaughters and Accidental Judgments, Canadian War Crimes Prosecutions, 1944-1948, Toronto: University of Toronto Press, 1997.

11. Convention on the Prevention and Punishment of the Crime of Genocide, (1951) 78 U.N.T.S. 277, [1949] C.T.S.27.

12. "Establishment of a Permanent International Criminal Court for the Punishment of Acts of Genocide," U.N. Doc. A/362, Annex.

13. G.A. Res. 489(V).

14. G.A. Res. 898(IX); G.A. Res. 1187(XII).

15. G.A. Res. 44/39.

16. "Draft Statute for an International Criminal Court," Official Records of the General Assembly, Forty-ninth Session, Supplement No. 10 (A/49/10), chap. II.B.I.5; and U.N. Doc. A/49/355. See: James Crawford, "The ILC's Draft Statute of an International Tribunal," (1994) 88 A.J.I.L. 140.

17. Statute of the International Criminal Tribunal for the Former Yugoslavia, S.C. Res. 827, Annex.

18. Statute of the International Criminal Tribunal for Rwanda, S.C. Res. 955, Annex.

19. G.A. Res. $49 / 53$.

20. "Report of the Ad Hoc Committee on the Establishment of an International CriminalCourt," Official Records of the General Assembly, Fiftieth Session, Supplement No. 22 (A/50/22).

21. G.A. Res. 50/46.

22. U.N. Doc. A/CONF.183/2/Add.1. See: Christopher Keith Hall, "The First Two Sessions of the UN Preparatory Committee on the Establishment of an International Criminal Court," (1997) 91 A.J.I.L. 177; Christopher Keith Hall, "The Third and Fourth Sessions of the UNPreparatory Committee on the Establishment of an International Criminal Court," (1997) 92 A.J.I.L. 124.

23. Rome Statute of the International Criminal Court, A/CONF.183/9.

24. For example: Optional Protocol to the International Covenant on Civil and Political Rights, (1976) 999 U.N.T.S. 171, [1976] C.T.S. 47 , art. 5(1)b).

25. Rome Statute, supra note 23, art. 20.

26. For example, Criminal Code, R.S.C. (1985), c. C-46, art. 7(3.71). See: Charles B. Wagner, "The Passing of legislation allowing for trial of those accused of war crimes and crimes against humanity," (1984) 4 Windsor Yearbook of Access to Justice 143.

27. See: Adolphus G. Karibi-Whyte, "The Twin ad hoc Tribunals and Primacy Over National Courts," (1998) 9 Criminal Law Forum (forthcoming).
28. Prosecutor v. Dusko Tadicaka Dule (IT-94-1AR72), August 10, 1995.

29. See: William A.Schabas, "Justice, Democracy and Impunity in Post-Genocide Rwanda: Searching for Solutions to Impossible Problems," (1997)7 Criminal Law Forum 523.

30. Rome Statute, supra note 23 , art. 5.

31. Ibid., art. 6.

32. Supra note 11 , art. II.

33. FrankChalk, "Toward a Generic Definition of Genocide," in George J. Andreopoulos, ed., Genocide: Conceptual and Historical Dimensions (Philadelphia: University of Pennsylvania Press, 1994).

34. Supra note 7, annex, art. 6(c).

35. Supra note 17 , art. 5.

36. Prosecutor v. Tadic (Case No. IT-94-1AR72), Judgment of the Appeals Chamber, October 2, 1995.

37. Rome Statute, supra note 23 , art. 7. See: David Donat-Cattin, "Crimes against Humanity," in Lattanzi, Flavia, ed., The International Criminal Court, Comments on the Draft Statute, Naples: Editoriale Scientifica, 1998, pp: 49-78.

38. Ibid., art. 7(3).

39. Ibid., art. 8(1).

40. Geneva Convention for the Amelioration of the Condition of the Wounded and Sick in Armed Forces in the Field, (1950) 75 U.N.T.S. 31, [1965] C.T.S. 20; Geneva Convention for the Amelioration of the Condition of the Wounded, Sick and Shipwrecked Members of the Armed Forces at Sea, (1950) 75 U.N.T.S. 85, [1965] C.T.S. 20; Geneva Convention Relative to the Treatment of Prisoners of War, (1950) 75 U.N.T.S. 135, [1965] C.T.S. 20; Geneva Convention Relative to the Protection of Civilians, (1950) 75 U.N.T.S. 287, [1965] C.T.S. 20.

41. Protocol Additional I to the 1949 Geneva Conventions and Relating to The Protection of Victims of International Armed Conflicts, (1979) 1125 U.N.T.S. 3, [1991] C.T.S. 2.

42. Protocol Additional II to the 1949 Geneva Conventions and Relating to The Protection of Victims of Non-International Armed Conflicts, (1979) 1125 U.N.T.S. 3, [1991] C.T.S. 2.

43. Rome Statute, supra note 23, art. $8(2)(b)(x x v i)$.

44. Ibid., art. $8(2)(b)(v i i i)$.

45. Ibid., art. 8(2)(b)(xviii).

46. Ibid., art. 8(2)(b)(xix).

47. Ibid., art. 8(2)(b)(xx). See: Roger S. Clark, "Methods of Warfare that Cause Unnecessary Suffering are Inherently Indiscriminate," (1998) 28 California Western Int'l L. J. 379. 
48. G.A. Res. 3314(XXIX).

49. Charter of the United Nations, [1945]

e.T.S

7, art. 39.

50. Rome Statute, supra note 23, art. 5(2). 51. Ibid., art. 12(2).

52. Cambodia acceded to the Genocide Conven tion on October 14, 1950, Rwanda on April 16, 1975. Other oft-cited candidates for international justice are also long-time participants in the Genocide Convention including Yugoslavia (August 29, 1950), Iraq (January 20, 1959), Congo (May 31, 1962), Iran (August 14, 1956), Afghanistan (March 22, 1956), Algeria (Octobe

$31,1963)$, and so on.

53. Supra note 12, art. 23(3)

54. United States of America v.

Yamashita,

(1948) 4 L.R.T.W.e. 1, 36-37; In re Yamashita, 327 U.S. 1 (1945); Canada v. Meyer (" Abbaye Ardenne Case"), (1948) L.R.T.W.e. 97, 109. On the Yamashita case, see: A. M. Prevost, "Race and War Crimes: The 1945 War Crimes Trial of General Tomoyaki Yamashita," (1992) 14 H.R.Q. 303; B. Landrum, "The Yamashit War Crime Trial: Command Responsibility Then and Now," (1995) 149 Mil. L. Rev.
293. On the Meyer case, see Patrick Brode, Casual Slaughters and Accidental Judgments, Toronto: University of Toronto Press, 1997.

55. Supra note 23, art. 86(2)

56. Article 7(3) of the Yugoslav Statute, supra note 17; art. 6(3) of the Rwanda Statute, supra note 18.

57. Rome Statute, supra note 23, art. 28.

58. Prosecutor v. Erdemovic (Case No. IT-96

22- T), Judgment of the Appeals Chamber, October 7,1997.

59. Rome Statute, supra note 23, art. 31(1)d).

60. Supra note 7, art. 8 .

61. Rome Statute, supra note 23, art. 33.

62. Ibid., art. 31(3)

63. Ibid., art. 13.

64. Ibid., art. 53.

65. Ibid., art. 42

66. Ibid., art. 36(8)(a)(iii).

67. Ibid., art. 38.

68. Ibid., art. 43

69. Ibid., arts. 57-58. 70.

Ibid., art. 54(l)(a)
71. Ibid., art. 65

2. International Covenant on Civil and

Political

Rights, (1976) 999 U.N.T.5. 171, [1976]

e.T.5. 47.

73. Ibid., arts. 55(2)(b), 67(1)(g)

74. Ibid., art. 67(1)(a).

75. Supra note 72, art. 14(3)(a).

76. Rome Statute, supra note 23, art. 67(1)(h).

77. Ibid., art. 67(1)(i).

78. Ibid., art. 77.

79. Ibid., art. 103.

80. Ibid., art. 110.

81. William A. Schabas, "Sentencing and the International Tribunals: For a Human Rights Approach," (1997) 7 Duke Journal of Comparative and International Law461-517.

82. David Donat-Cattin, "The Role of Victims in the ICC Proceedings," in Lattanzi, Flavia, ed., The International Criminal Court Comments on the Draft Statute, Naples: Editoriale Scientifica, 1998, pp. 251-72.

83. Ibid., art. 79.

84. Ibid., art. 86

85. Ibid., art. 59(1). 86. Ibid.,

arts. $89,102 .:: J$

\section{Refugee Rights Report on a Comparative Survey}

By James C. Hathaway and John A. Dent

Toronto:. Xork.Lane\$Pre;:\$ , 1995; JSBj'N 1-55014-2()6-6; 82 page;::; \$11.95

Are visa controls inte;:nded to ke;:ep re;:fuge;::;:s from reaching an asylum country le;:gal? Can asylum-see;:kers le;:gitimately conte;:st conditions of detention? At what point do refugee;:s have the right to work, or to claim social assistance?

The;:se are;: among the many issue;:s addre;:ssc;:d by RefUgeeRight\$: Report on a Comparative Survey. a ground-breaking analysis of th human rights of re£ug eSarO $1 \mathrm{nA}$ the world. Working in collaborat,ion with thirty renowned legal experts from Europe. Africa, Asia, Oceania, North America. and Latin Ame;:rica, ProfessorJames Hathaway, Osgoode Hall Law School, York University, and John Dent, Senior Re;:search Associate, International Refugee Rights Project, Osgoode Hall Law School, York University, analyze the international legal instruments that set the human rights of refugee;:s. By grounding their analysis. in real.,life challenges facing Jefugee;:s today, Hathaway and Denthave produced a book as valuable to activists as ioscholars.

RefUgee Rights will provoke debate on the adequacy of the international refugee;: rights regime. It is e;:ssc;:ntial reading for everyone concerned to counter threats to the human dignity of refugees.

$$
\text { Availabk.from: }
$$

CentrerorRefUge StUdies, York University Suite 333, York Lanes. 4700 Keele St., Toronto ON M3J IP3 Fax: (416) 736-5837 ${ }^{\bullet}$ Email: refuge@yorku.ca 